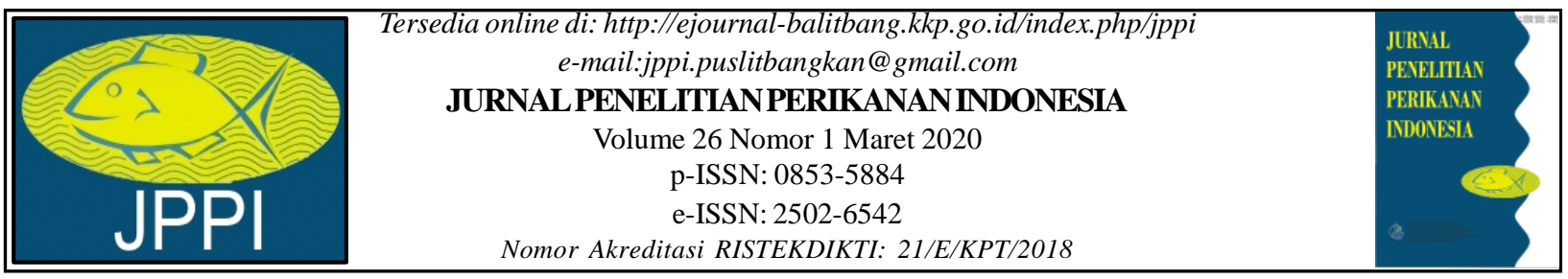

Nomor Akreditasi RISTEKDIKTI: 21/E/KPT/2018

\title{
PEMANFAATAN DAN PENGELOLAAN TUNA NERITIK DI WILAYAH PENGELOLAAN PERIKANAN NEGARA REPUBLIK INDONESIA (WPPNRI) 573
}

(Studi kasus perikanan tuna neritik berbasis di PPN Prigi-Trenggalek-Jawa Timur)

\author{
THE UTILIZATION AND MANAGEMENT OF NERITIC TUNA FISHERIES \\ IN FISHERIES MANAGEMENT AREA REPUBLIC OF INDONESIA (FMA-RI) 573 \\ (Case study of neritic tuna fisheries based at Prigi Fishing Port-Trenggalek-East Java)
}

\author{
Agustinus Anung Widodo*1, Ignatius Tri Hargiyatno', Regi Fiji Anggawangsa' dan Wudianto' \\ ${ }^{1}$ Pusat Riset Perikanan, Gedung. BRSDMKP II, JI. Pasir Putih 2, Ancol Timur, Jakarta Utara-14430, Indonesia \\ Teregistrasi I tanggal: 24 Juli 2019; Diterima setelah perbaikan tanggal: 31 Desember 2019; \\ Disetujui terbit tanggal: 07 Februari 2020
}

\begin{abstract}
ABSTRAK
Dalam rangka mendeskripsikan pemanfaatan dan inisiasi pengelolaan perikanan tuna neritik di WPPNRI 573, telah dilakukan penelitian dengan mengambil kasus perikanan tuna neritik berbasis di PPN Prigi-Jawa Timur. Data diperoleh melalui program port sampling pada tahun 2013-2017. Hasil penelitian menunjukkan produksi tuna neritik yaitu tongkol lisong (BLT), tongkol krai (FRI), tongkol komo (KAW), dan tongkol abu-abu (LOT) rata-rata sebesar 8.120 ton per tahun. Dari jumlah tersebut, 99,56\% diproduksi melalui perikanan pukat cincin (PS) dan sisanya dari perikanan jaring insang hanyut $\left({ }_{d} G N\right)$, payang (DS), dan pancing tonda-pancing ulur (TR- $\mathrm{HL}$ dan ${ }_{d} \mathrm{HL}$ ). CPUE nominal PS selama 5 tahun terakhir terus menurun, rata-rata 0,891 ton/hari. Komposisi jenis tangkapan PS meliputi BLT (91,52\%), FRI (6,68\%), KAW (1,78\%) dan LOT (0,01\%). Sebanyak 99\% BLT yang tertangkap PS merupakan ikan yuwana, sedangkan FRI, KAW, dan LOT sebagian besar tertangkap pada ukuran dewasa masing sebanyak $73 \%, 70 \%$, dan $55 \%$. Tuna neritik termasuk spesies peruaya jauh, maka pengelolaannya di WPPNRI 573 harus mengacu pada acuan pengelolaan Indian Ocean Tuna Commission (IOTC). Mengacu hasil Work Party Neritic Tuna (WPNT) IOTC tahun 2016 dan 2018, maka pengelolaan perikanan tuna neritik di WPPNRI 573 berbasis di PPN Prigi adalah sebagai berikut: (1) hingga 2025 jumlah hasil tangkapan BLT dan FRI harus dikendalikan masing-masing pada jumlah 9.818 ton dan 48 ton per tahun; (2) hingga 2023 tangkapan KAW ditetapkan pada jumlah \pm 98 ton per tahun (80\% jumlah tangkapan tahun 2013); dan (3) hingga tahun 2025 jumlah tangkapan LOT disarankan sama dengan tangkapan 2015 yaitu \pm 1.13 ton per tahun.
\end{abstract}

Kata Kunci: Pemanfaatan; pengelolaan; tuna neritik; WPPNRI 573

\section{ABSTRACT}

To describe the utilization and management initiation of tuna neritic fisheries in the Indonesian FMA-RI 573, a research has been conducted by taking the case at the Prigi Fishing Port, East Java. Data were obtained through the port sampling program in 2013-2017. Results show that the production of neritic tuna, namely bullet tuna (BLT), frigate tuna (FRI), kawa-kawa (KAW), and longtail tuna (LOT) was 8,120 tons per year on average. $99.56 \%$ of the amount were produced by purse seine (PS) fisheries, the rest came from drifting gill nets $\left(_{d} G N\right)$, danish-seine (DS), and the combination of trolling line and surface-deep hand line (TR- $H L$ and $\left.{ }_{d} H L\right)$ fisheries. The nominal CPUE of PS over the past 5 years has continued to decline, averaging 0.891 tons/day. The composition of PS catches includes BLT (91.52\%), FRI (6.68\%), KAW (1.78\%) and LOT (0.01\%). Large numbers (99\%) of the BLT caught by PS were juvenile fish, while at the same time FRI, KAW, and LOT were mostly caught at the adult stage. Neritic tuna is a highly migratory species, so its management in the Indonesian FMARI 573 must refer to the Indian Ocean Tuna Commission- 
IOTC recommendations. Referring to the results of WPNT-IOTC in 2016 and 2018, the management of neritic tuna fisheries in the Indonesian FMA-RI 573 based at Prigi Fishing Port is as follows: (1) up to 2025, the catches of BLT and FRI must be controlled at 9,818 and 48 tons per year, respectively;

(2) up to 2023, the catches of KAW are set at \pm 98 tons per year (80\% of the total catch in 2013); and

(3) up to 2025, the catch of LOT is recommended the same as in 2015, which is \pm 1.13 tons per year.

\section{Keywords: Exploitation; management; neritic tuna; the Indonesian FMA-RI 573}

\section{PENDAHULUAN}

Pengelolaan perikanan di Indonesia salah satunya adalah berbasis wilayah yang terbagi menjadi 11 Wilayah Pengelolaan Perikanan Negara Republik Indonesia (WPPNRI). WPPNRI 573 merupakan salah satu dari 11 WPPNRI yang mencakup perairan Samudera Hindia selatan Jawa hingga selatan Nusa Tenggara. Secara regional, WPPNRI 573 termasuk ke dalam area pengelolaan Indian Ocean Tuna Commission (IOTC). IOTC mempunyai mandat melakukan pengelolaan perikanan tuna, tuna neritik dan hasil tangkapan sampingan pada perikanan tuna di Samudera Hindia. Indonesia merupakan salah satu negara anggota IOTC, sehingga pengelolaan tuna neritik di WPPNRI 573 harus sejalan dan mengacu kebijakan yang diberlakukan IOTC.

Sumber daya tuna neritik yang dikelola IOTC meliputi tongkol krai atau tongkol lurik atau frigate tuna (Auxis thazard-FRI), tongkol lisong atau bullet tuna (Auxis rochei-BLT), tongkol komo atau kawakawa/eastern little tuna (Euthynnus affinis-KAW) dan tongkol abu-abu dan longtail tuna (Thunnus tonggolLOT) serta sheerfish yang meliputi tenggiri papan (Scomberomorus guttatus-GUT) dan tenggiri (Scomberomorus commerso-COM) (Herrera et al., 2009). Sejauh ini data dan informasi tentang sumber daya tuna neritik yang dimiliki IOTC relatif kurang dibanding data dan informasi jenis tuna tropis (cakalang, madidihang, dan tuna mata besar). Kondisi ini menyebabkan ketidakpastian dalam pengelolaan Neritik tuna di wilayah ini. Dalam rangka mengumpulkan informasi dan mengembangkan langkah pengelolaan yang tepat, IOTC melaksanakan Working Party on Neritik Tuna (WPNT-IOTC) yang diikuti negara-negara anggotanya setiap tahun yang dimulai sejak tahun 2011.

Pemanfaatan tuna neritik di WPPNRI 573 dilakukan dengan menggunakan pukat cincin (purse seine-PS), jaring insang hanyut (drifting gillnet- ${ }_{\mathrm{d}}^{\mathrm{GN}}$ ), bagan (lift net-LN), payang (danish seine-DS), kombinasi pancing tonda dan pancing ulur permukaan (combination trolling and surface hand line, TR-sHL). Basis perikanan PS, ${ }_{d}$ GN, LN, DS dan TR-sHL di WPPNRI 573 menyebar mulai dari pantai selatan wilayah Provinsi-Provinsi: Banten, Jawa Barat, Jawa Tengah, Jawa Timur, Bali, Nusa Tenggara Barat hingga
Nusa Tenggara Timur. Prigi-Trenggalek merupakan salah satu sub basis perikanan PS, ${ }_{d}$ GN, DS, dan TR-sHL di Jawa Timur dengan dengan total alat penangkapan ikan (API) sebanyak 842 unit dan produksi tuna neritik sebanyak $14.971,5$ ton pada 2013 dan jumlah API naik menjadi 974 unit namun produksi produksi menurun menjadi 4.699,4 ton pada 2017.

Secara nasional data dan informasi tentang tuna neritik juga relatif kurang dibandingkan dengan data dan informasi mengenai sumber daya tuna tropis. Oleh karena itu langkah-langkah pengelolaan perikanan neritik tuna di Indonesia saat ini, termasuk di WPPNRI 573 masih difokuskan pada perbaikan data dan informasi melalui program log-book penangkapan, port sampling program dan program observer. Dalam rangka mendeskripsikan pemanfaatan dan inisiasi pengelolaan perikanan tuna neritik di WPPNRI 573 dilakukan penelitian dengan mengambil kasus perikanan tuna neritik yang berbasis di PPN Prigi,Trenggalek, Jawa Timur.

\section{BAHAN DAN METODE}

Data dan informasi yang digunakan pada tulisan meliputi aspek perikanan termasuk daerah penangkapan dan aspek biologi. Data aspek perikanan diperoleh dari program port sampling program yang dilakukan oleh enumerator PPN Prigi periode 2013-2017. Data daerah penangkapan termasuk posisi rumpon (fish aggregating devicesFADs) diperoleh dari kantor PPN Prigi yang tercatat pada 2017 dan 2018. Data aspek biologi terutama terkait jenis (species) dan ukuran panjang cagak (fork lenght, FL) ikan diperoleh dari kegiatan port sampling program yang dilakukan enumerator Pusat Riset Perikanan dari Maret 2015 hingga Desember 2016. Jenis ikan diidentifikasi mengacu pada Compagno (1999) dan Sainsbury et al. (1985).

Inisiasi langkah-langkah pengelolaan adalah mengacu hasil analisis length at first captured $\left(\mathrm{L}_{c}\right)$ dengan length at first of maturity $\left(\mathrm{L}_{\mathrm{m}}\right)$ serta rekomendasi dari Working Party on Neritic Tuna IOTC(WPNT-IOTC). $\mathrm{L}_{c}$ adalah ukuran panjang rata-rata dimana ikan pertama kali tertangkap suatu alat penangkapan ikan (API). Udoh et al. (2017) menyampaikan $L_{c}$ merupakan salah satu informasi ilmiah penting yang dibutuhkan dalam pengelaolaan 
perikanan berkelanjutan. $\mathrm{L}_{\mathrm{m}}$ adalah panjang rata-rata dari populasi ikan tertentu menjadi dewasa secara seksual untuk pertama kalinya. $\mathrm{L}_{m}$ merupakan salah satu indikator penting dalam manajemen sumberdaya perikanan Beverton et al. (1956) dan Tuda et al. (2016).

Ukuran FL ikan dianalisis untuk mendapatkan ukuran pertama kali tertangkap $L_{c}$. $L_{c}$ merupakan $50 \%$ dari kumulatif persentase ikan yang tertangkap masing-masing alat penangkapan ikan (API) sehingga $\mathrm{L}_{c}=\mathrm{L}_{50 \%}$. Formulasi tersebut merupakan pengembangan dari kurva seleksi API yang dikemukakan Sparre et al. (1998) yaitu $L_{c}=L_{50 \%}$ Nilai $\mathrm{L}_{m}$ sebagian besar merujuk pada hasil penelitian yang dilakukan peneliti lain karena belum tersedia hasil penelitian tersebut di Indonesia. Nilai $L_{m} B L T$ adalah
35,0 cm (Kahraman, 2010), nilai $L_{m} F R I$ adalah 30,8 cm (jantan) dan 32,8 cm (betina) (Jude at al., 2002). Nilai $L_{m}$ KAW yang tertangkap ${ }_{d}$ GN berkisar antara 43-46 cm (Muthiah, 1985; Pillai et al., 2003; Masuswo et al., 2016) dan yang tertangkap PS adalah $43 \mathrm{~cm}$ (Faizal et al., 2017) dan nilai $\mathrm{L}_{\mathrm{m}} \mathrm{LOT}$ adalah $\mathrm{FL} 60 \mathrm{~cm}$ (Griffiths, 2010).

\section{HASIL DAN BAHASAN \\ Hasil}

\section{Alat Penangkapan Ikan (API)}

API yang terdaftar berbasis di PPN Prigi yang memproduksi tuna neritik meliputi PS, ${ }_{d}$ GN, DS, dan TR- ${ }_{s} \mathrm{HL}$ (Tabel 1).

Tabel 1. Jumlah unit alat penangkapan ikan (API) yang potensial menangkap tuna neritik yang berbasis di PPN Prigi, 2013-2017.

Table 1. Number of unit fishing gears that potential caught neritic tuna based at Prigi Fishing Port, 2032017.

\begin{tabular}{lcccccc}
\hline & \multicolumn{5}{c}{ (Number of unit of Fishing Gear) } \\
\cline { 2 - 7 } $\begin{array}{c}\text { Tahun } \\
\text { (Year) }\end{array}$ & $\begin{array}{c}\text { Pukat } \\
\text { Cincin } \\
\text { (PS) }\end{array}$ & $\begin{array}{c}\text { Jaring } \\
\text { Insang } \\
\text { Hanyut (dGN) }\end{array}$ & $\begin{array}{c}\text { Payang } \\
\text { (DS) }\end{array}$ & $\begin{array}{c}\text { Tonda-Pancing } \\
\text { Ulur } \\
\text { Permukaan } \\
\text { (TR-sHL) }\end{array}$ & $\begin{array}{c}\text { Pancing } \\
\text { Ulur Dasar } \\
\left({ }_{b} \text { HL) }\right.\end{array}$ & Total \\
\hline 2013 & 131 & 17 & 13 & 80 & 601 & 842 \\
2014 & 135 & 18 & 13 & 83 & 617 & 866 \\
2015 & 133 & 17 & 13 & 81 & 608 & 852 \\
2016 & 155 & 20 & 15 & 95 & 705 & 990 \\
2017 & 152 & 20 & 15 & 93 & 694 & 974 \\
\hline
\end{tabular}

Sumber: PPN Prigi (2017)

Source: Prigi Fishing Port (2017)

\section{Estimasi Daerah Penangkapan Ikan}

Daerah penangkapan ikan (DPI) adalah suatu perairan yang memenuhi persyaratan teknis dan ekonomis bagi suatu API bila dioperasikan di perairan tersebut. Persyaratan teknis yang harus dipenuhi diantaranya operasional API dapat dilakukan dengan mudah tanpa hambatan dan tidak mengalami peristiwa laut yang ekstrim seperti arus air dan angin yang sangat kuat. Persyaratan ekonomi yang harus dipenuhi diantaranya perairan tersebut tidak terlalu jauh dari basis pendaratan dan kelimpahan ikan cukup tinggi sehingga jumlah hasil tangkapan dapat optimum.

Pengamatan terhadap kapal-kapal PS, GN, DS, dan TR- ${ }_{s} \mathrm{HL}$ serta ${ }_{b} \mathrm{HL}$ yang berbasis di PPN Prigi menunjukkan bahwa kapal-kapal tersebut tidak dilengkapi peralatan untuk mendapatkan informasi tentang parameter lingkungan perikanan laut. Nelayan
PS dan TR- ${ }_{s} \mathrm{HL}$ pada umumnya menggunakan alat bantu penangkapan ikan (ABPI) berupa rumpon berjangkar (anchored fish aggregating devices, ${ }_{\mathrm{a}} \mathrm{FADs}$ ). ${ }_{\mathrm{a}}$ FADs dipasang di DPI yang potensial yaitu mempunyai arus laut tidak kencang, kedalaman sekitar $3.000 \mathrm{~m}$ dan bukan alur pelayaran. Sebanyak 57 unit ${ }_{\mathrm{a}}$ FADs didaftarkan nelayan ke PPN Prigi pada 2017, tersisa menjadi hanya 21 unit pada 2018 (Gambar 1). Berkurangnya jumlah rumpon sebagian besar hilang akibat badai besar yang terjadi pada Agustus 2018.

\section{Hasil Tangkapan}

Total tuna neritik yang tertangkap PS, ${ }_{d}$ GN, DS, TR- $\mathrm{sL}$ dan ${ }_{\mathrm{b}} \mathrm{HL}$ yang berbasis di PPN Prigi selama 5 tahun terakhir (2013-2017) berturut-turut adalah $14.971,1$ ton; $9.987,1$ ton; $8.944,8$ ton; $2.003,7$ ton; dan $4.693,4$ ton (Tabel 2) dengan rata-rata $8.120,3$ ton per tahun. 

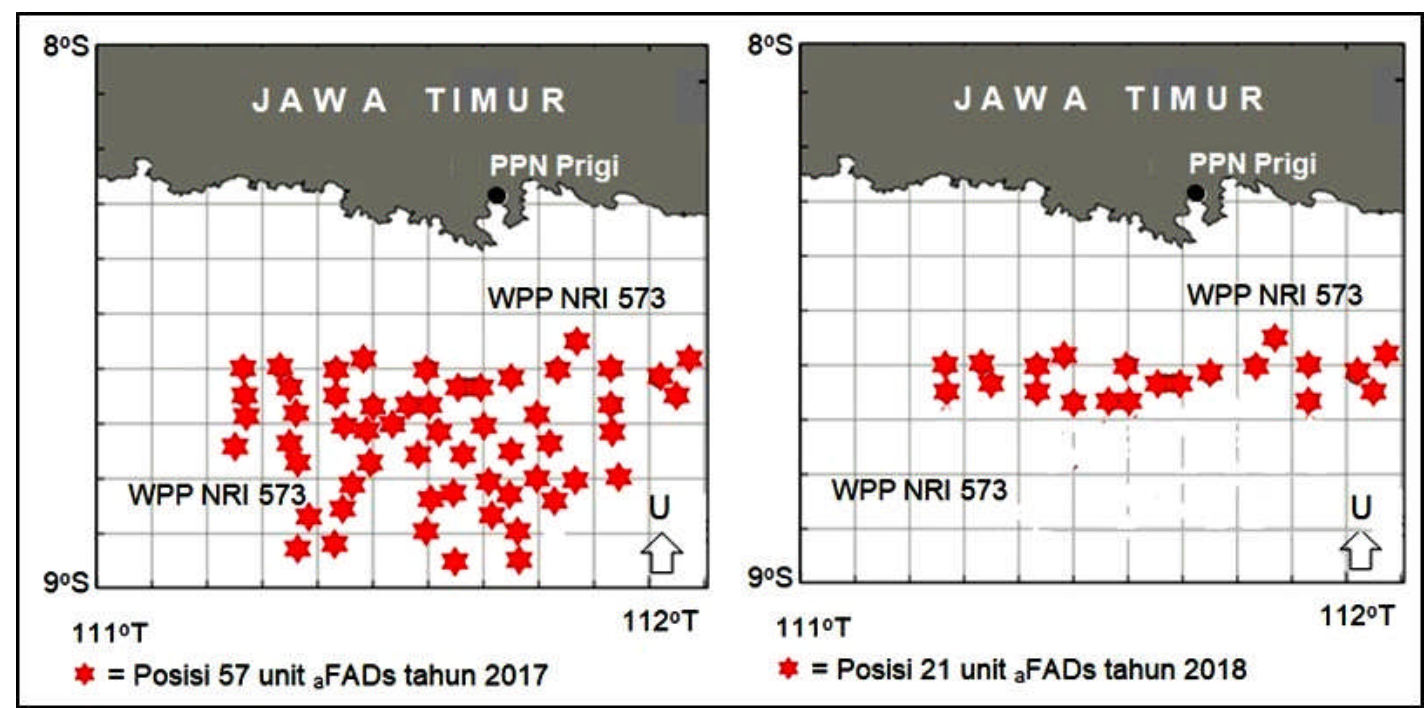

Gambar 1. Posisi ${ }_{\mathrm{a}} \mathrm{FADs}$ yang mengindikasikan daerah penangkapan PS dan $\mathrm{TR}-{ }_{\mathrm{s}} \mathrm{HL}$ yang berbasis di PPN Prigi (PPN Prigi, 2018).

Figure 1. The ${ }_{a} F A D$ s position where indicate fishing ground of PS and TR-sHL based at Prigi Fishing Port (PPN Prigi, 2018).

Tabel 2. Hasil tangkapan tuna neritik API (PS, $\left.{ }_{d} G N, P L, T R-H L\right)$ berbasis di PPN Prigi pada 2013-2017

Tabel 2. Catch of neritic tuna caught by PS, GN, PL, and TR-HL based at Prigi fishing port in 2013-2017.

\begin{tabular}{rrrrrr}
\hline Tahun & \multicolumn{6}{c}{ Hasil tangkapan tuna neritik (Catch of neritic tuna) (TON) } \\
\cline { 2 - 6 } (Year) & \multicolumn{1}{c}{ BLT } & FRI & KAW & LOT & \multicolumn{1}{c}{ Total } \\
\hline 2013 & $12.661,2$ & $2.187,4$ & 122,0 & 0,9 & $14.971,5$ \\
2014 & $9.818,1$ & 47,8 & 120,4 & 0,8 & $9.987,1$ \\
2015 & $8.351,1$ & 392,2 & 200,4 & 1,1 & $8.944,8$ \\
2016 & $1.916,2$ & 33,0 & 53,6 & 0,9 & $2.003,7$ \\
2017 & $4.410,4$ & 57,8 & 228,0 & 1,2 & $4.697,4$ \\
\hline
\end{tabular}

PS merupakan API yang paling banyak memproduksi tuna neritik dibandingkan dengan 4 API lainnya. Hasil tangkapan per upaya (catch per unit effort-CPUE) nominal (non-stadardized CPUE) masing-masing API (Tabel 3). CPUE nominal PS menurun dari $\pm 1,39$ ton/trip pada 2013 menjadi $\pm 0,89$ ton/trip pada 2017. Trip panangkapan PS adalah trip harian (daily trip) adapun trip penangkapan DS dan TR- ${ }_{s} \mathrm{HL}$ rata-rata 8 hari/trip dan ${ }_{b} \mathrm{HL}$ rata-rata 6 hari/ trip. Trip penangkapan PS adalah harian (daily trip), trip penangkapan ${ }_{d} G N$ rata-rata 8 hari/trip, trip penengkapan DS adalah harian (daily trip), trip penangkapan TR rata-rata 8 hari/trip, trip penangkapan TR rata-rata 6 hari/trip.

Komposisi hasil tangkapan tuna neritik pada masing-masing API sebagai berikut PS (99,56\%), ${ }_{d} \mathrm{GN}$ $(0,03 \%)$, DS $(0,08 \%)$, TR- $\mathrm{HL}(0,32 \%)$ dan ${ }_{\mathrm{b}} \mathrm{HL}$ $(0,01 \%)$. Adapun komposisi jenis tuna neritik yang tertangkap PS, masing-masing adalah $91,52 \% \mathrm{BLT}$, $6,68 \% \mathrm{FRI}, 1,78 \%$ KAW dan 0,01\% LOT. Tuna neritik yang didaratkan di PPN Prigi umumnya diolah sebagai ikan pindang, asap dan sebagian kecil dikonsumsi segar.

\section{Ukuran Ikan}

Ukuran tuna neritik yang tertangkap diperoleh dari port sampling program terhadap hasil tangkapan PS berbasis di PPN Prigi dari Maret 2015 hingga Oktober 2016 dengan ukuran yang bervariasi (Gambar 2). Ukuran panjang cagak ikan (FL) berkisar antara 1634 ( $\mathrm{md} \mathrm{26}$ ) cm, 18-46 ( $\mathrm{md} \mathrm{38}$ ) cm, 24-66 ( $\mathrm{md} \mathrm{48)} \mathrm{cm}$, dan 34-78 ( $m$ d 64) cm masing-masing untuk BLT, FRI, KAW, dan LOT. Gambar 2 menyajikan distribusi ukuran ikan tuna neritik yang tertangkap PS yang berbasis di PPN Prigi port sampling program Maret 2015 hingga Oktober 2016. 
Tabel 3. CPUE PS, dGN, DS, TR-sHL dan bHL berbasis di PPN Prigi pada 2013-2017.

Table 3. CPUE of PS, dGN, DS, TR-sHL and bHL based at Prigi Fishing Port in 2013-2017.

\begin{tabular}{|c|c|c|c|c|c|c|c|}
\hline $\begin{array}{l}\text { Tahun } \\
\text { (Year) }\end{array}$ & $\begin{array}{c}\text { API } \\
\text { (Gear) }\end{array}$ & \multicolumn{2}{|c|}{$\begin{array}{c}\text { Jumlah Upaya } \\
\text { (Trip } \\
\text { penangkapan }^{\star \star \star} \text { ) } \\
\text { Number of Effort } \\
\text { (Fishing trip) }\end{array}$} & $\begin{array}{c}\text { Hasil } \\
\text { Tangkapan } \\
\text { (Catch) } \\
\text { Tuna Neritik } \\
\text { (TON) }\end{array}$ & $\begin{array}{c}\text { Hasil } \\
\text { Tangkapan } \\
\text { Ikan } \\
\text { Lainnya } \\
\text { (Catch of } \\
\text { other fish) } \\
\text { (TON) }\end{array}$ & $\begin{array}{c}\text { Total } \\
\text { hasil } \\
\text { tangkapa } \\
\text { n (Total } \\
\text { Catch) } \\
\text { (TON) }\end{array}$ & $\begin{array}{l}\text { CPUE } \\
\text { tuna } \\
\text { neritik } \\
\text { (ton/trip } \\
\text { sukses) }\end{array}$ \\
\hline \multirow[t]{6}{*}{2013} & $\left.\mathrm{PS}^{* *}\right)$ & 10.779 & 7.554 & 14.967 & 10.402 & 25.369 & 1,3886 \\
\hline & $d G N$ & 976 & 937 & 6 & 170 & 176 & 0,0061 \\
\hline & DS & 569 & 531 & 2 & 354 & 356 & 0,0040 \\
\hline & $\mathrm{TR}$ & 906 & 906 & 1 & 3.882 & 3.883 & 0,0010 \\
\hline & $\mathrm{HL}$ & 8.368 & 7.791 & 0 & 41 & 41 & 0,0000 \\
\hline & Total & - & - & 14.975 & 14.849 & 29.824 & \\
\hline \multirow[t]{6}{*}{2014} & $\left.\mathrm{PS}^{\star *}\right)$ & 9.915 & 6.696 & 9973 & 6471 & 16.444 & 1,4890 \\
\hline & dGN & 516 & 495 & 1 & 66 & 67 & 0,0020 \\
\hline & DS & 138 & 138 & 6 & 178 & 184 & 0,0430 \\
\hline & TR & 778 & 776 & 7 & 339 & 346 & 0,0090 \\
\hline & $\mathrm{HL}$ & 3.455 & 3.445 & 0 & 17.719 & 17.719 & 0,0001 \\
\hline & Total & & - & 9.986 & 24.773 & 34.759 & - \\
\hline \multirow[t]{6}{*}{2015} & $\left.\mathrm{PS}^{* *}\right)$ & 11.228 & 8.137 & 8876 & 12.313 & 21.189 & 1,0908 \\
\hline & dGN & 890 & 868 & 3 & 73 & 76 & 0,0035 \\
\hline & DS & 969 & 958 & 11 & 852 & 863 & 0,0115 \\
\hline & TR & 1.072 & 1.072 & 55 & 1.034 & 1.089 & 0,0513 \\
\hline & $\mathrm{HL}$ & 6.768 & 6.371 & 1 & 796 & 797 & 0,0002 \\
\hline & Total & - & - & 8.946 & 15.068 & 24.014 & - \\
\hline \multirow[t]{6}{*}{2016} & $\left.\mathrm{PS}^{* *}\right)$ & 2.674 & 1.671 & 1.995 & 460 & 2.485 & 1,1939 \\
\hline & dGN & 531 & 496 & 1 & 28 & 29 & 0,0020 \\
\hline & DS & 242 & 235 & 2 & 92 & 94 & 0,0085 \\
\hline & TR & 635 & 631 & 6 & 424 & 430 & 0,0095 \\
\hline & $\mathrm{HL}$ & 7.662 & 7.344 & 0 & 1.128 & 1.128 & 0,0001 \\
\hline & Total & - & - & 2.004 & 2.162 & 4.166 & \\
\hline \multirow[t]{6}{*}{2017} & PS & 8.787 & 5.185 & 4.616 & 11.303 & 15.919 & 0,8903 \\
\hline & dGN & 614 & 614 & 1 & 46 & 47 & 0,0016 \\
\hline & DS & 740 & 734 & 10 & 628 & 638 & 0,0136 \\
\hline & TR & 1.356 & 1.340 & 63 & 1.386 & 1.449 & 0,0470 \\
\hline & $\mathrm{HL}$ & 2.761 & 2.723 & 4 & 146 & 150 & 0,0015 \\
\hline & Total & - & - & 4.696 & 13.509 & 18.205 & \\
\hline
\end{tabular}

Sukses berarti mendapatkan hasil tangkapan.

*) _ Purse seine pelagis kecil

- Umumnya melakukan trip harian 


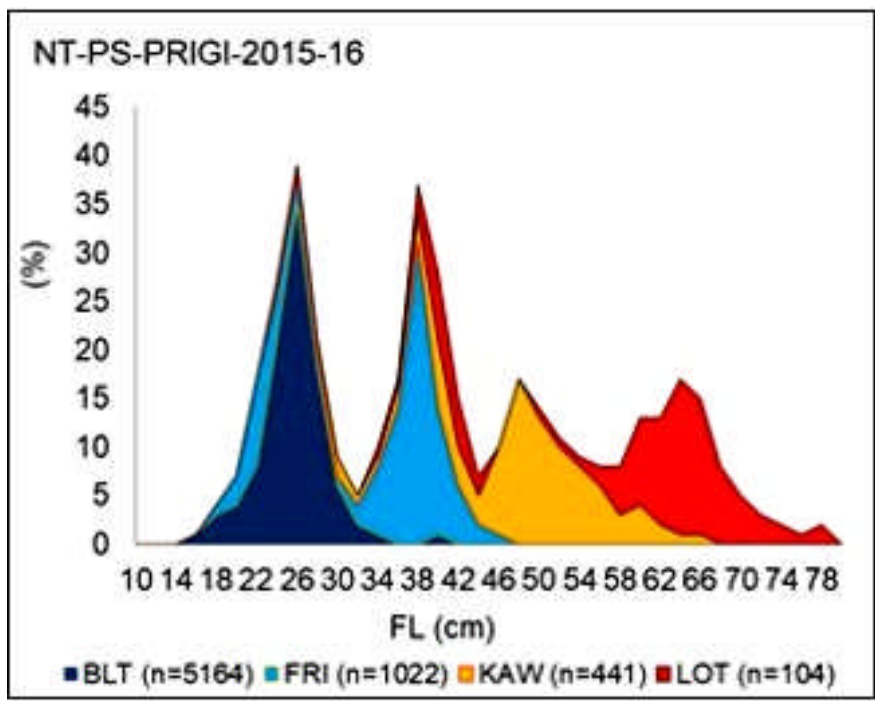

Gambar 2. Distribusi ukuran panjang cagak (FL) tuna neritik (NT) yang meliputi tongkol lisong (Auxis rochei$\mathrm{BLT}$ ), tongkol lurik (Auxis thazard-FRI), tongkol komo (Euthynnus affinis-KAW) dan tongkol abuabu ( Thunnus tonggol-LOT) yang tertangkap PS berbasis di PPN Prigi bulan Maret 2015-Februari 2016.

Figure 2. Fork length (FL) size distribution of neritic tunas (NT) include BLT, FRI, KAW and LOT caught by PS based at Prigi Fishing Port through port sampling program March 2015-February 2016.

Hasil analisis terhadap distribusi ukuran panjang cagak (FL) ikan BLT, FRI, KAW dan LOT yang tertangkap pada Maret 2015 - Februari 2016 menunjukkan bahwa nilai ukuran panjang pertama kali ikan tertangkap $\left(\mathrm{L}_{\mathrm{c}}\right)$ secara berturutan adalah $\mathrm{BLT}(24,8$ $\mathrm{cm})$, FRI (34,2 cm), KAW (47,6 cm) dan LOT $(60,0$ $\mathrm{cm})$ seperti disajikan pada Gambar 3.

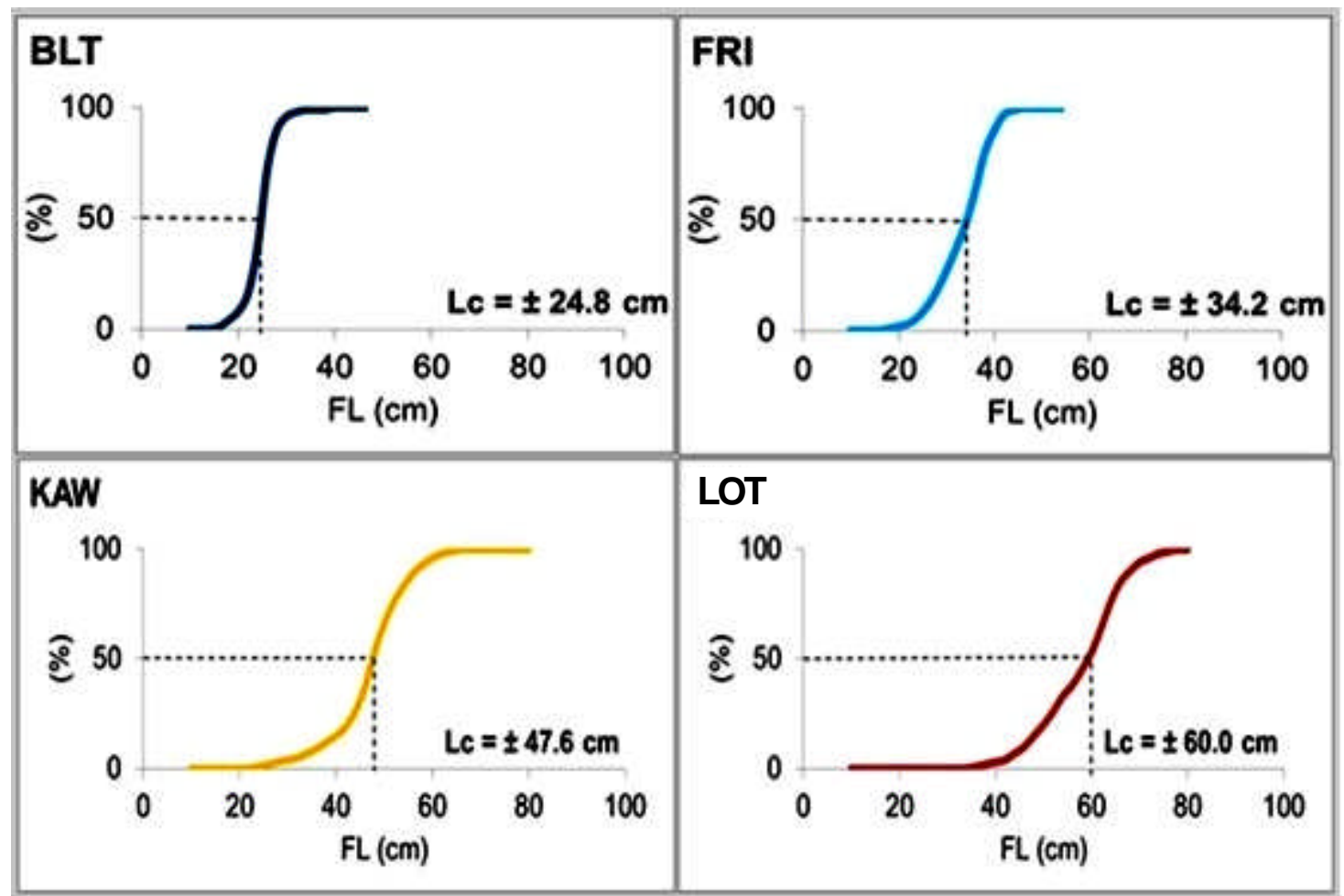

Gambar 3. Kurva selektivitas PS berbasis di PPN Prigi terhadap BLT, FRI, KAW dan LOT yang tertangkap pada Maret 2015 - Februari 2016.

Figure 3. Selectivity curve of PS based at Prigi Fishing Port to BLT, FRI, KAW and LOT that caught in March 2015 - February 2016. 


\section{Bahasan}

PS merupakan API yang paling banyak menangkap tuna neritik dibanding 4 API lainnya dengan komposisi produksi masing-masing API sebagai berikut PS $(99,56 \%)$, ${ }_{d}$ GN $(0,03 \%)$, DS $(0,08 \%), \mathrm{TR}-\mathrm{HL}(0,32 \%)$ dan ${ }_{\mathrm{b}} \mathrm{HL}(0,01 \%)$. Adapun komposisi jenis tuna neritik yang tertangkap PS, GN, DS, TR- $\mathrm{HL}$ dan $\mathrm{HL}$ adalah $91,52 \% \mathrm{BLT}, 6,68 \%$ FRI, $1,78 \%$ KAW dan 0,01 \% LOT. Hasil per upaya penangkapan (catch per unit effort-CPUE) nominal (non-standardized CPUE) masing-masing API adalah sebagaimana disajikan Tabel 3. CPUE nominal PS menurun dari $1.388 \mathrm{~kg} /$ trip pada tahun 2013 menjadi $525 \mathrm{~kg} /$ trip pada tahun 2017. Trip panangkapan PS adalah trip harian adapun trip penangkapan DS dan TR- ${ }_{s} \mathrm{HL}$ rata-rata 8 hari/trip dan ${ }_{b} \mathrm{HL}$ rata-rata 6 hari/ trip. Tuna neritik yang didaratkan di PPN Prigi umumnya diolah sebagai ikan pindang, asap dan sebagian kecil dikonsumsi segar.

Parameter kunci dari ekosistem perikanan laut yang biasa digunakan dalam pengembangan pemodelan untuk memprediksi DPI diantaranya adalah temperatur permukaan laut (sea surface temperature-SST), konsentrasi klorofil-a (chloro-phyll-a concentration atau $\mathrm{Chl}-\mathrm{a}$ ), dan turunan data lingkungan lainnya seperti gradien suhu, kisaran SST, data arus dan permukaan tinggi laut atau sea surface high-SSH (Zhou et al., 2016). Kapal-kapal yang menangkap tuna neritik yang berbasis di PPN Prigi tidak dilengkapi peralatan untuk mendapatkan informasi tentang kunci dari ekosistem perikanan laut yang biasa digunakan untuk menentukan DPI, oleh karena itu nelayan hanya mengandalkan pengalaman yang dipunyai saja.

Nilai $L_{c}$ sering diperbandingkan dengan nilai $L_{m}$ suatu spesies ikan yang tertangkap suatu API untuk melihat keadaan suatu perikanan. Jika nilai $L_{c}>L_{m}$ maka keadaan tersebut dianggap baik karena spesies ikan yang tertangkap tersebut umumnya merupakan ikan-ikan dewasa dengan asumsi telah melakukan pemijahan (spawning) paling sedikit satu kali sebelum tertangkap. Jika ikan yang tertangkap tersebut telah melakukan pemijahan (spawning) paling sedikit satu kali sebelum tertangkap maka akan terhindar dari terjadinya 'recruitment overfishing' maupun 'growth overfishing'(Murawski, 2000). Jika diperbandingkan antara nilai $L_{c}$ dengan nilai $L_{m}$ maka pada riset maka $B L T$, FRI, dan LOT mempunyai nilai $L_{c}>L_{m}$ dan hanya KAW yang mempunyai nilai $\mathrm{L}_{c}<\mathrm{L}_{\mathrm{m}}$ nya.

Tabel 4. Nilai $L_{c} i k a n$ BLT, FRI, KAW dan LOT yang tertangkap PS berbasis di PPN Prigi 2018 dan nilai $L_{m}$ BLT, FRI, KAW dan LOT berdasarkan hasil riset sebelumnya di Samudera Hindia.

Table 4. $L_{c}$ of BLT, FRI, KAW and LOT caught by PS based at Prigi Fishing Port 2018 and $L_{m}$ of BLT, FRI, $K A W$ and LOT based on previous research in Indian Ocean.

\begin{tabular}{|c|c|c|c|}
\hline $\begin{array}{l}\text { Spesies } \\
\text { (Species) }\end{array}$ & $\begin{array}{l}\text { Ukuran panjang pertama } \\
\text { tertangkap (Length of first } \\
\text { captured-Lc base on } \\
\text { research }\end{array}$ & $\begin{array}{c}\text { Ukuran panjang mulai } \\
\text { dewasa (Length of first } \\
\left.\text { mature- } L_{m}\right)\end{array}$ & $\begin{array}{l}\text { Sumber } \\
\text { Source }\end{array}$ \\
\hline BLT & $24,80 \mathrm{~cm}$ & $23,60 \mathrm{~cm}$ & Jasmine, et al. (2013) \\
\hline FRI & $34,20 \mathrm{~cm}$ & $29,70 \mathrm{~cm}$ & Ghosh, et al. (2012) \\
\hline KAW & $47,60 \mathrm{~cm}$ & $48,40 \mathrm{~cm}$ & Ekawaty, et al. (2018) \\
\hline LOT & $60,00 \mathrm{~cm}$ & $53,50 \mathrm{~cm}$ & Griffiths, et al. (2019 \\
\hline
\end{tabular}

Berdasarkan hasil analisis tersebut, maka kondisi $\mathrm{BLT}$, FRI, dan LOT pada perikanan PS di Prigi dapat terhindar dari terjadinya 'recruitment overfishing' maupun 'growth overfishing'. Hal ini senada dengan temuan Suryaman et al. (2017) bahwa dengan metoda PSA menunjukkan umumnya nilai productivity $(p)$ ikan tuna neritik lebih besar dibandingkan nilai susceptability (s) sehingga kapasitas penangkapan dapat ditingkatkan. Namun demikian untuk sumber daya KAW perlu mendapat perhatian khusus karena $>50 \%$ hasil tangkapan PS merupakan ikan yuwana sehingga dapat berakibat terjadi 'growth overfishing'. Ikan yuwana pada paper ini adalan ikan yang mempunyai ukuran FL lebih kecil dari ukuran $L_{m}$ nya.

Dalam salah satu peraturan internasional dinyatakan bahwa pengelolaan perikanan ditujukan untuk memastikan keberlanjutan jangka panjang sumber daya ikan dengan mempromosikan pemanfaatan sumber daya perikanan secara optimum, memelihara kelestarian sumber daya tersebut untuk generasi kini dan generasi mendatang (Article 7 Code of Conduct Responsible Fisheries-CCRF terbitan FAO, 1995). Terkait sumber daya tuna, Direktorat Jenderal Perikanan Tangkap telah menyusun RPP tuna, cakalang dan tongkol yang juga memuat rencana aksinya hingga tahun 2019 (DGCF, 2014). Perikanan tongkol yang dimaksud pada rencana aksi adalah perikanan tuna neritik yaitu perikanan yang terkait dengan sumber daya BLT, FRI, KAW dan LOT. Di dalam rencana aksi terdapat 94 Sasaran Aksi (SA) dan 618 Rencana Aksi (RA). 
Beberapa RA terkait sumber daya tuna neritik (BLT, FRI, KAW dan LOT ) yang telah dan sedang dilaksanakan adalah melakukan: (1) estimasi jumlah hasil tangkapan per trip penangkapan kapal PS, ${ }_{d} \mathrm{GN}$, PL, TR-HL; (2) kajian komposisi hasil tangkapan PS yang berasosiasi dengan rumpon; dan (3) kajian estimasi potensi dan tingkat pemanfaatan tuna neritik (MSY, $F_{\text {current }} / F_{\text {MSY, }} \mathrm{SB}_{\text {curren }} / \mathrm{SB}_{\text {MSY }}$ ). RA butir 1 dan butir 2 telah dilaksanakan sejak 2015 oleh KKP, sedangkan RA butir 3 dilakukan secara regional oleh
Indian Ocean Tuna Commission (IOTC). Collette et al. (1983) menyampaikan tuna neritik sebagian hidupnya berada di perairan dekat pantai (namun diketahui juga bahwa tongkol lisong dan tongkol krai bersifat oceanik dan kosmopolitan perairan hangat (Anon., 2006). Dari kenyataan itu maka IOTC juga melakukan kajian stok tuna neritik pada tingkatan regional. Kegiatan kajian stok tuna neritik oleh IOTC terbaru adalah pada 2016 dan 2018 dengan resume hasil seperti disajikan dalam Tabel 5.

Tabel 5. Rangkuman hasil kajian stok tuna neritik oleh IOTC pada 2016 dan 2018.

Table 5. Summary of stock assessment on tuna neritic by IOTC in 2016 and 2018.

\begin{tabular}{|c|c|c|c|}
\hline $\begin{array}{l}\text { Spesies } \\
\text { (Species) }\end{array}$ & $\begin{array}{c}\text { Tahun Kajian Stok } \\
\text { (Year of Stock } \\
\text { Assessment) }\end{array}$ & $\begin{array}{l}\text { Status Stok } \\
\text { (Stock Status) }\end{array}$ & $\begin{array}{c}\text { Saran Pengelolaan } \\
\text { (Management Recommendation) }\end{array}$ \\
\hline BLT & IOTC (2016) & $\begin{array}{l}\text { Belum dapat } \\
\text { ditentukan }\end{array}$ & $\begin{array}{l}\text { Dilakukan dengan prinsip kehati- } \\
\text { hatian, jumlah tangkapan tidak boleh } \\
\text { lebih dari rata-rata hasil tangkapan } \\
\text { tahun } 2010-2014 \text {. }\end{array}$ \\
\hline FRI & IOTC (2016) & $\begin{array}{l}\text { Belum dapat } \\
\text { ditentukan }\end{array}$ & $\begin{array}{l}\text { Dilakukan dengan prinsip kehati- } \\
\text { hatian, jumlah tangkapan tidak boleh } \\
\text { lebih dari rata-rata hasil tangkapan } \\
\text { tahun } 2010-2014 \text {. }\end{array}$ \\
\hline KAW & IOTC (2018) & $\begin{array}{l}\text { Tidak overfished dan } \\
\text { tidak overfishing }\end{array}$ & $\begin{array}{l}\text { Walaupun tidak overfished dan tidak } \\
\text { overfishing, namun tetap disarankan } \\
\text { agar jumlah hasil tangkapan } 2016- \\
2023 \text { berjumlah } 80 \% \text { dari tangkapan } \\
2013 \text { sehingga stok dapat berada di } \\
\text { atas MSY pada tahun } 2023 \text {. }\end{array}$ \\
\hline LOT & IOTC (2018) & $\begin{array}{l}\text { Mengalami } \\
\text { overfished dan } \\
\text { overfishing }\end{array}$ & $\begin{array}{l}\text { Jumlah tangkapan dipertahankan } \\
\text { seperti hasil tangkapan tahun } 2015 \text {, } \\
\text { maka diharapkan stok akan } \geq \mathrm{MSY} \\
\text { pada tahun } 2025 \text {. }\end{array}$ \\
\hline
\end{tabular}

Dari jumlah hasil tangkapan (Tabel 3), terlihat bahwa 99,56\% tertangkap oleh PS, oleh karena itu pengelolaan perikanan tuna neritik berbasis di PPN Prigi difokuskan pada pengelolalan perikanan PS. Berdasarkan laporan working party of neritic tuna (WPNT) IOTC pada 2016 direkomendasikan agar jumlah tangkapan BLT dan FRI hingga tahun 2020 harus tidak melebihi hasil tangkapan tahun 2014 (IOTC, 2016). Stok sumber daya KAW, tidak mengalami overfihed dan overfishing, namun berdasarkan matrik 'Kobe strategy Il' yang dibuat pada 2015 menunjukkan bahwa jika jumlah hasil tangkapan tetap dipertahankan seperti jumlah tangkapan pada 2013 maka akan tarjadi overfishing pada 2023. Overfishing sumber daya KAW dapat dihindari dengan cara mengurangi jumlah tangkapan sebanyak $20 \%$ terhadap hasil tangkapan pada 2013. Berdasarkan kajian stok sebagaimana dilaporkan pada WPNT-IOTC tahun 2018 menunjukkan bahwa sumber daya LOT mengalami overfished dan overfishing. IOTC menyarankan pengelolaan LOT dengan cara mempertahankan jumlah hasil tangkapan pada tahuntahun mendatang disamakan dengan volume hasil tangkapan pada 2015. Dengan cara melaksanakan saran tersebut, maka stok LOT akan pulih e" MSY pada 2025 (IOTC, 2018). Guna mendukung pekerjaan kajian stok oleh IOTC pada 2025 yang lebih akurat, semua negara anggota termasuk Indonesia diminta menyediakan data yang lebih akurat. Data tersebut meliputi CPUE masing-masing API dan ukuran (panjang dan berat) ikan yang tertangkap setiap spesies.

Jika mengacu saran pengelolaan IOTC tersebut, maka untuk perikanan tuna neritik berbasis di PPN Prigi adalah sebagai berikut: (1) hingga 2025 jumlah hasil tangkapan BLT dan FRI harus dikendalikan masing-masing pada jumlah 9.818 ton dan 48 ton; (2) hingga 2023 jumlah hasil tangkapan KAW ditetapkan pada jumlah \pm 98 ton $(80 \%$ dari jumlah tangkapan tahun 2013. Dikarenakan bahwa tongkol lisong dan tongkol krai bersifat oseanik dan 
kosmopolitan perairan hangat (Anon., 2006), maka WPNT-IOTC pada 2012 menyarankan agar dilakukan kerja sama pengelolaan neritik tuna (IOTC, 2012).

\section{KESIMPULAN}

Hasil tangkapan gabungan tuna neritik (BLT, FRI, KAW dan LOT) di WPPNRI 573 dengan basis pendaratan PPN Prigi selama 5 tahun terakhir (20132017) rata-rata sebesar 8.120 ton per tahun. Dari jumlah tersebut, 99,56\% berasal dari perikanan PS dan siasanya oleh perikanan $\mathrm{GN}(0,03 \%)$, DS $(0,08 \%), T R-{ }_{s} H L(0,32 \%)$ dan ${ }_{b} H L(0,01 \%)$. Komposisi jenis tuna neritik yang tertangkap PS dan didaratkan di PPN Prigi sebesar 91,52 \% BLT, 6,68 \% FRI, 1,78 $\%$ KAW dan 0,01\% LOT. CPUE nominal (non-standardized CPUE) PS menurun dari tahun ke tahun selama 5 tahun terakhir dengan rata-rata 0,891 ton/hari.

Tuna neritik jenis BLT, FRI, dan LOT umumnya tertangkap pada ukuran telah dewasa sehingga dapat terhindar dari terjadinya 'recruitment overfishing' maupun 'growth overfishing'. Namun demikian untuk sumber daya KAW perlu mendapat perhatian khusus karena $>50 \%$ hasil tangkapan PS merupakan ikan yuwana sehingga dapat berakibat terjadi 'growth overfishing'. Ikan yuwana pada paper ini adalan ikan yang mempunyai ukuran FL lebih kecil dari ukuran $L_{m}$ nya.

\section{PERSANTUNAN}

Data dan informasi yang digunakan pada paper ini adalah bagian dari data dan informasi dari kegiatan penelitian harvest strategy bagi sumberdaya ikan tuna neritik di WPPNRI 571, 572 dan 573 yang dibiayai oleh DIPA Pusriskan tahun 2018. Kontributor utama dari karya tulis ilmiah ini adalah Agustinus Anung Widodo.

\section{DAFTAR PUSTAKA}

Anonymous. (2006). Compilation of information on neritic tuna species in the Indian Ocean. A working paper, IOTC-2006-SC-INF11.

Beverton, R.J.H., \& Holt, S.J. (1956). A review of methods for estimating mortality rates in exploited fish populations, with special reference to sources of bias in catch sampling. Rapports et ProcèsVerbaux des Rèunl ons Commission Internationale pour l'Exploration Scientifique de la Mer Méditerranée, 140, 67-83.

Collette, B.B., \& Nauen, C. E. (1983). FAO species catalogue. Vol. 2. Scombrids of the world. An annotated and illustrated catalogue of tunas, mack- erels, bonitos and related species known to date. FAO Fish. Synop. 125(2). 137.

Compagno. L.J.V. (1999). The living marine resource of the western central pacific Vol. 3 FAO. Rome. p.1398-1529.

DGCF. (2014). National plan of action-national managemen tuna plan of Indonesia. Directorate General of Capture Fisheries-Ministry of Marine Affairs and Fisheries Republic of Indonesia-Book120pp.

Faizal E. M., Jamon, S., Jamaludin, N.A., \& Basir, S. (2017). Neritic tuna fishery and some biological aspects of kawakawa (Euthynnus affinis) in the Malacca Straits. IOTC-2017-WPNT07-20. 12p.

Ekawaty, R., \& Jatmiko, I. (2018). Biologi reproduksi ikan tongkol komo, Euthynnus affinis (Cantor, 1849). di Samudra Hindia Bagian Timur. Jurnal Iktiologi Indonesia, 18(3), 199-208. DOI: https:// doi.org/10.32491/jii.v18i3.313.

FAO. (1995). Code of Conduct for Responsible Fisheries. Rome, FAO. 41p. ISBN 92-5-103834.

Ghosh, S., Sivadas, M., Abdussamad, E. M., Rohit, P., Said, K.P., Koya, K., Joshi, K., Chellappan, A., Rathinam, M. M., Prakasan, D., \& Sebastine, M. (2012). Fishery, population dynamics and stock structure of frigate tuna Auxis thazard (Lacepede, 1800 ) exploited from Indian waters. Indian Journal of Fisheries. 59(2), 95-100.

Griffiths, S.P. (2010). Stock assessment and efficacy of size limits on longtail tuna (Thunnus tonggol) caught in Australian waters. Fisheries Research. 102, 248-257. https://doi.org/10.1016/ j.fishres.2009.12.004

Griffiths, S.P., Zischke, M.T., Velde, T.v.d., \& Fry, G. C. (2019) Reproductive biology and estimates of length and age at maturity of longtail tuna (Thunnus tonggol) in Australian waters based on histological assessment. Marine and Freshwater Research, CSIRO Publishing, January 2019, 12p. https://doi.org/10.1071/MF18469.

Murawski. S.A. (2000). Definitions of overfishing from an ecosystem perspective. ICES Journal of Marine Science, 57, 649-658. doi:10.1006/ jmsc.2000.0738.

Kahraman, A., Göktürk, D., Bozkurt, E.R., Akayl, T., \& Karakulak, F.S. (2010). Some reproductive as- 
pects of female bullet tuna, Auxis rochei (Risso), from the Turkish Mediterranean coasts. African Journal of Biotechnology, 9(40), 6813-6818.

Herrera, M., \& Pierre, L. (2009). Status of IOTC Databases for Neritic Tunas. IOTC-2009-WPDCS-06.

IOTC (2012). Report of the $2^{\text {nd }}$ Session of the IOTC Working Party on Neritic Tunas. Penang, Malaysia, 19-21 November 2012. IOTC-2012-WPNT02$\mathrm{R}[\mathrm{E}]:$ 70pp.

IOTC (2016). Report of the $6^{\text {th }}$ Session of the IOTC Working Party on Neritic Tunas. Mahé, Seychelles, 21-24 June 2016. IOTC-2016WPNT06-R[E]: $89 \mathrm{pp}$.

IOTC (2018). Report of the $8^{\text {th }}$ Session of the IOTC Working Party on Neritic Tunas. Mahe, Seychelles, 21 - 24 August 2018. IOTC-2018WPNT08-R[E]: 73 pp.

Jasmine, S., Rohit, P., Abdussamad, E. M., Said, K. P., Koya, K., Joshi, K., Kemparaju, S., Prakasan, D., Elayathu, M. N. K., \& Sebastine, M. (2013). Biology and ûshery of the bullet tuna, Auxis rochei (Risso, 1810) in Indian Waters. Indian Journal of Fisheries, 60(2), 13-20.

Jude, D., Neethiselvan, N., Gopalakrishnan, P., \& Sugumar, G. (2002). Gillnet selectivity studies for fishing frigate tuna, Auxis thazard Lecepede (Perciformes/Scombridae) in Thoothukkudi (Tuticorin) waters, southeast coast of India. Indian Journal of Marine Sciences, 31(4), 329-333.

Sainsbury, K.J., Kailola, P.J., \& Leyland, G.G. (1985). Continental Shelf Fishes of Nothern and NorthWestern Australia. CSIRO Division of Fisheries Research-Canbera-Autralia. $375 \mathrm{p}$.
Zhou, W., Chen, X., Cui, X., Fan, W., Yang S., Tang F., Fan X, Hua, C., Wu, Y., Zhang, H., \& Zhang, S. (2016). The Fishing Ground Analysis and Forecasting Information System for Chinese Oceanic Fisheries. In: Bian F., Xie Y. (eds) Geo-Informatics in Resource Management and Sustainable Ecosystem. Communications in Computer and Information Science, vol 569-pp 882-889. Springer, Berlin, Heidelberg ISBN 978-3-662-49154-6 (Print) and 978-3-662-49155-3 (on-line).

Sparre, P., \& Venema, S.C. (1998). Introduction to Tropical Fish Stock Assessment -Part 1 and 2. FAO Fish. Tech.PaperNo.306/2.Rev.2. FAO.

Suryaman, E., Boer, M., Adrianto, L., \& Sadiyah, L. (2017). Analisis produktivitas dan suseptibilitas pada tuna neritik di Perairan Pelabuhanratu. J.Llit.Perikan.Ind, 23 (1), 19-28.

Tuda, P.M., Wolff, M., \& Breckwoldt, A. (2016) Size structure and gear selectivity of target species in the multispecies multigear fishery of the Kenyan South Coast. Journal of Ocean \& Coastal Management 130 (2016) 95-106. Elsevier. Journal homepage: www.elsevier.com/locate/ocecoaman.

Udoh, J.P., \& Ukpatu, J. E. (2017). First estimates of growth, recruitment pattern and length-at-first-capture of Nematopalaemon hastatus (Aurivillius, 1898) in Okoro River estuary, southeast Nigeria. AACL Bioflux, 10, (5), 1074- 1084. http:// www.bioflux.com.ro/aacl. 